\title{
Yield of Three Range Grasses Grown Alone and in Mixtures with Legumes
}

\author{
W.J. MCGINNIES AND C.E. TOWNSEND
}

\section{Abstract}

Four legumes and 3 grasses in combination, and the 3 grasses alone were evaluated for forage yield and persistence for 9 years in north-central Colorado. Sicklepod milkvetch (Astragalus falcatus), alfalfa (Medicago sativa), sainfoin (Onobrychis viciifolia) or crownvetch (Coronilla varia) were planted in alternate rows with crested wheatgrass (Agropyron desertorum), Russian wildrye (Elymus junceus), or pubescent wheatgrass (A. trichophorum). Crownvetch failed to become established. Sainfoin, a short-lived species under Colorado range conditions, was gone within 5 years. Alfalfa persisted 7 years; it was killed by a combination of drought and pocket gophers. Sicklepod milkvetch persisted for the entire period. This site was too dry for pubescent wheatgrass and its stand declined rapidly. Crested wheatgrass with sicklepod milkvetch or alfalfa, and Russian wildrye with alfalfa produced the highest total yields. All grass-legume mixtures involving crested wheatgrass and Russian wildrye produced significantly more forage than the grasses grown alone in $30 \mathrm{~cm}$ row spacing. Crude protein content was higher for grass-legume mixtures than for the grass alone.

Planting legumes with grasses for range seedings has been a common recommendation. This recommendation has usually been based on the assumption that because legumes can fix nitrogen, the legume will serve to increase total production. It has also been assumed that because legumes usually have a higher protein content than grasses, the protein content of the mixture will be higher. These assumptions are based on a limited number of studies. In North Dakota, a crested wheatgrass-alfalfa mixture produced $45 \%$ more forage than crested wheatgrass alone (Rogler and Lorenz 1969). Crude protein of the forage from the crested wheatgrassalfalfa mixture was $136 \%$ of that from crested wheatgrass alone. The crude protein of the grass from the grass-legume mixture was slightly higher than from the grass when grown alone. Rumbaugh et al. (1981) reported that crested wheatgrass-alfalfa mixture produced four times the yield of crested wheatgrass alone, and that the grass component of the mixture produced twice as much forage as when the grass was planted without the alfalfa. Thus, the increase in productivity of the mixture was due to both the increased yield of the grass component plus the addition of the legume component. In Canada, alfalfa alone yielded $12 \%$ more than a crested wheatgrass-alfalfa mixture which in turn yielded 68\% more than crested wheatgrass alone (Ludwick and Smith 1977). Protein content of the crested wheatgrass component of the mixture was $41 \%$ greater than the protein content of the grass when grown alone.

The objectives of this study were to determine the influence of 4 legumes on forage yield and quality when planted with 3 range grasses in north-central Colorado.

\footnotetext{
Authors are range scientist and geneticist, respectively, USDA, ARS, Crops Research Laboratory, Colorado State University, Fort Collins, Colorado 80523.

This research involved cooperative investigations of USDA, ARS, Fort Collins, Colo. and the Colorado Agricultural Experiment Station. Published with approval of the Director of the Colorado Agricultural Experiment Station.

Manuscript received July 6, 1982.
}

\section{Methods and Procedures}

The experimental site was on the Colorado State University Experimental Range approximately $13 \mathrm{~km}$ north of Fort Collins, Colo. The soil, a Stoneham loan (Ustollic Haplargid) was a deep, well-drained soil formed from mixed alluvial and wind-deposited material. Native vegetation was shortgrass; the area had been farmed for many years but was planted to crested wheatgrass (Agropyron desertorum) about 10 years before the current study was established. Elevation was $1,580 \mathrm{~m}$ and long-term average annual precipitation was $36 \mathrm{~cm}$ measured in Fort Collins.

The plot area was plowed in September 1970 and disked in April 1971. It was harrowed and packed just prior to seeding on May 13, 1971. Grasses were planted in 6 rows $60 \mathrm{~cm}$ apart except for the grass-only plots where the rows were $30 \mathrm{~cm}$ apart. The legumes were seeded equidistant between the grass rows. The grasses were 'Nordan' crested wheatgrass (Agropyron desertorum), 'Vinall' Russian wildrye (Elymus junceus), and 'Topar' pubescent wheatgrass (A. trichophorum); the legumes were sicklepod milkvetch (Astragalus falcatus), 'Ladak 65' alfalfa (Medicago sativa), 'Eski' sainfoin (Onobrychis viciifolia) and 'Penngift' crownvetch (Coronilla varia). Seeding rate was 98 pure live seed $/ \mathrm{m}$ of row and planting depth was $2 \mathrm{~cm}$. All species were seeded with a single-row cone seeder equipped with a double-disc opener and a packer wheel. Legume seeds were scarified and inoculated with a suitable rhizobium. Plot size was $3.4 \times 7.6 \mathrm{~m}$. Experimental design was a randomized complete block with 4 replications. Alternate rows of grasses and legumes minimized interspecific competition during establishment and greatly simplified the separate harvesting of the grass and legume components. Plots were hand weeded twice during the first year.

Seedling stands were rated in September 1971 on a percentage basis where a continuous and uninterrupted row of plants within the seeded drill-row equaled $100 \%$ and no stand at all equaled $0 \%$.

Seven harvests were made between 1972 and 1980 with a catcherequipped rotary mower to a stubble height of $5 \mathrm{~cm}$. Herbage from grass and legume rows was collected in separate catchers and random grab samples from each catcher were taken for oven-dry weight determinations. The average harvest date was June 20 . This is near maximum standing herbage for crested wheatgrass, about 2 weeks past maximum for Russian wildrye, and about 2 weeks early for pubescent wheatgrass. All legumes were flowering at the harvest date.

Plant material for chemical analyses came from the oven-dried samples (dried at $60^{\circ} \mathrm{C}$ ). Soil material for chemical analyses was collected from between the rows and was a composite of 5 subsamples from the surface $15 \mathrm{~cm}$ in each plot. Nitrogen was determined by a Kjeldahl procedure (Isaac and Johnson 1976). Percentage crude protein was calculated by $\% \mathrm{~N} \times 6.25$. Phosphorus from plant materials was measured using a colorimetric procedure; for soil phosphorus, a bicarbonate extraction was made.

All data were analyzed and evaluated by analysis of variance techniques, and correlation statistics were computed as needed to evaluate relationships among measured factors.

\section{Results and Discussion}

Growing conditions in 1971 were generally favorable, and good 
to excellent stands were obtained for all species except crownvetch. Stand ratings in September, 1971 were as follows:

$\begin{array}{lr}\text { Crested wheatgrass } & 96 \% \\ \text { Russian wildrye } & 92 \% \\ \text { Pubescent wheatgrass } & 99 \% \\ \text { Sicklepod milkvetch } & 82 \% \\ \text { Alfalfa } & 100 \% \\ \text { Sainfoin } & 92 \% \\ \text { Crownvetch } & 40 \%\end{array}$

All species survived the winter of 1971-72 in good condition except for crownvetch, which had almost completely disappeared by the spring of 1972.

In spite of a severe drought in 1976 and 1977, crested wheatgrass and Russian wildrye stands were still excellent in 1980. Pubescent wheatgrass declined slowly before 1976 , but it was severely damaged by the drought in 1977. In 1980, over half of the plots containing pubescent wheatgrass did not contain enough plants to sample. Those plots that retained a partial stand of pubescent wheatgrass had fairly high yields because the grass plants that remained were widely spaced and individually were very productive. Pubescent wheatgrass plots were heavily invaded by weeds, while the crested wheatgrass and Russian wildrye plots were almost weed-free. When the study was established, we realized that this site was probably marginal for pubescent wheatgrass. This severe decline in pubescent wheatgrass should be kept in mind when evaluating the results that follow.

$F$ values for differences among years and treatments for percentage legume in the mixture and for yield were significant $(p<0.01)$. Although sicklepod milkvetch never contributed as high a percentage to the yield as did alfalfa and sainfoin, it maintained itself with little decline through 1980 (Table 1). Sainfoin produced high yields in the first harvest (1972) but subsequently declined and had disappeared from the plots by 1978 . The decline apparently was not drought induced, because the decline occurred during favorable as well as dry years. Based on this and other studies (Townsend et al. 1975), we believe sainfoin is a short-lived species on rangelands and its decline and demise was expected.

Alfalfa also declined and disappeared from the crested wheatgrass and Russian wildrye plots by 1980 . Fair to poor stands of alfalfa persisted in the pubescent wheatgrass plots because the greatly reduced grass stand provided less competition during dry years than did the full and vigorous stands of crested wheatgrass and Russian wildrye. The reduction of alfalfa appeared to be caused by the combined effects of drought and pocket gophers (Thomomys talpoides). Pocket gophers were first found in these plots in 1973. They were trapped out each year but they usually reinvaded the plots during the winter. Pocket gophers cut stems and tap roots below ground level. They would usually go along a seeded row killing or severely damaging all the plants they encountered. This damage in combination with drought stress eliminated most of the alfalfa. Most of the pocket gopher damage was confined to alfalfa; they only rarely damaged sicklepod milkvetch, sainfoin, or the grasses.

The highest average yields over the period 1972 through 1980 were from sicklepod milkvetch with crested wheatgrass, and alfalfa with crested wheatgrass and Russian wildrye (Table 2). Herbage production for plots containing sainfoin was usually lower than comparable plots containing sicklepod milkvetch or alfalfa, even during the early years of the study before sainfoin had seriously declined in stand. However, in 1980, when sainfoin was completely gone from these plots, yields of crested wheatgrass and Russian wildrye were substantially higher in the sainfoin plots than in the comparable plots with a row spacing of $60 \mathrm{~cm}$. We suspected that the decomposing sainfoin plants had an effect on residual soil $\mathbf{N}$ during the earlier years, but soil $N$ in 1980 in the sainfoin plots $(717 \mu \mathrm{g} \mathrm{N} / \mathrm{g}$ ) was not higher than in the check treatments $(756 \mu \mathrm{g}$ $\mathrm{N} / \mathrm{g})$.

During the period 1972 through 1980 , the average yields for all legume and row space treatments were $2,616 \mathrm{~kg} /$ ha for crested wheatgrass, $2,251 \mathrm{~kg} /$ ha for Russian wildrye, and $1,945 \mathrm{~kg} / \mathrm{ha}$ for pubescent wheatgrass. Production of crested wheatgrass and Russian wildrye in $60 \mathrm{~cm}$ rows averaged $22 \%$ more than in rows $30 \mathrm{~cm}$ apart. Both crested wheatgrass and Russian wildrye are welladapted to this site. If the grass is to be cut for hay, crested wheatgrass is preferred because its more upright growth form makes haying easy while Russian wildrye is extremely difficult to harvest as hay. Russian wildrye may be preferred for grazing because of its higher palatability and better regrowth capabilities.

Sicklepod milkvetch had the best persistence of the legumes. It was also effective in increasing total yield when planted with crested wheatgrass or Russian wildrye. Sicklepod milkvetch has been reported to be potentially toxic to livestock (Williams et al. 1976). However, we know of no cases of livestock poisoning from sicklepod milkvetch. Sicklepod milkvetch is easier to establish than many legumes used for range seeding including cicer milkvetch (Astragalus cicer) (Townsend and McGinnies 1972), and it has generally shown good persistence in rangeland seedings.

Crude protein content of both grass and legume herbage in 1978 and 1980 was above the recommended 7 to $9 \%$ (NRC 1970) usually suggested as a maintenance ration for livestock on rangeland. Crude protein content of the legume component averaged 17.4 and $17.2 \%$ in 1978 and 1980 , respectively, and was 30 to $85 \%$ higher than the grass component of the various grass-legume mixtures. Crude protein content of the grasses averaged $9.8 \%$ in 1978 and $11.3 \%$ in 1980 . Protein content of the mixtures was intermediate

Table 1. Percent of legume herbage in grass-legume mixtures harvested in June 1972 through 1980.

\begin{tabular}{|c|c|c|c|c|c|c|c|c|}
\hline Grass and legume & 1972 & 1973 & 1974 & 1975 & 1976 & 1978 & 1980 & Mean \\
\hline $\begin{array}{l}\text { Crested wheatgrass } \\
\text { Sicklepod milkvetch } \\
\text { Alfalfa } \\
\text { Sainfoin } \\
\text { Crownvetch }\end{array}$ & $\begin{array}{r}13 \\
47 \\
46 \\
0\end{array}$ & $\begin{array}{r}10 \\
44 \\
31 \\
0\end{array}$ & $\begin{array}{r}11 \\
41 \\
24 \\
0\end{array}$ & $\begin{array}{r}21 \\
40 \\
26 \\
0\end{array}$ & $\begin{array}{r}25 \\
51 \\
21 \\
0\end{array}$ & $\begin{array}{r}25 \\
38 \\
0 \\
0\end{array}$ & $\begin{array}{r}19 \\
0 \\
0 \\
0\end{array}$ & $\begin{array}{r}18 \\
37 \\
21 \\
0\end{array}$ \\
\hline $\begin{array}{l}\text { Russian wildrye } \\
\text { Sicklepod milkvetch } \\
\text { Alfalfa } \\
\text { Sainfoin } \\
\text { Crownvetch }\end{array}$ & $\begin{array}{r}34 \\
72 \\
77 \\
0\end{array}$ & $\begin{array}{r}20 \\
58 \\
50 \\
0\end{array}$ & $\begin{array}{r}14 \\
48 \\
16 \\
0\end{array}$ & $\begin{array}{r}31 \\
52 \\
16 \\
0\end{array}$ & $\begin{array}{r}24 \\
56 \\
10 \\
0\end{array}$ & $\begin{array}{r}12 \\
31 \\
0 \\
0\end{array}$ & $\begin{array}{r}18 \\
0 \\
0 \\
0\end{array}$ & $\begin{array}{r}22 \\
45 \\
24 \\
0\end{array}$ \\
\hline $\begin{array}{l}\text { Pubescent wheatgrass } \\
\text { Sicklepod milkvetch } \\
\text { Alfalfa } \\
\text { Sainfoin } \\
\text { Crownvetch }\end{array}$ & $\begin{array}{r}12 \\
48 \\
51 \\
0\end{array}$ & $\begin{array}{r}15 \\
57 \\
56 \\
0\end{array}$ & $\begin{array}{r}16 \\
55 \\
45 \\
0\end{array}$ & $\begin{array}{r}45 \\
67 \\
37 \\
0\end{array}$ & $\begin{array}{r}30 \\
68 \\
19 \\
0\end{array}$ & $\begin{array}{r}100 \\
85 \\
0 \\
0\end{array}$ & $\begin{array}{r}35 \\
53 \\
0 \\
0\end{array}$ & $\begin{array}{r}36 \\
62 \\
30 \\
0\end{array}$ \\
\hline Isd 0.051 & 11.7 & 9.4 & 14.7 & 16.4 & 22.4 & 26.8 & 33.9 & 12.0 \\
\hline
\end{tabular}

'Least significant difference, $\alpha=0.05$. 
Table 2. Herbage yield (metric tons/ha) of grass alone and grass-legume mixtures harvested 1972 through 1980.

\begin{tabular}{|c|c|c|c|c|c|c|c|c|}
\hline Treatment & 1972 & 1973 & 1974 & 1975 & 1976 & 1978 & 1980 & Mean \\
\hline $\begin{array}{l}\text { Crested wheatgrass } \\
\text { Sicklepod milkvetch } \\
\text { Alfalfa } \\
\text { Sainfoin } \\
\text { Grass only } 60 \mathrm{~cm} \text { rows } \\
\text { Grass only } 30 \mathrm{~cm} \text { rows }\end{array}$ & $\begin{array}{l}2.57 \\
1.83 \\
1.70 \\
2.63 \\
2.41\end{array}$ & $\begin{array}{l}3.18 \\
2.84 \\
2.82 \\
3.52 \\
2.50\end{array}$ & $\begin{array}{l}3.20 \\
3.55 \\
2.79 \\
2.03 \\
2.04\end{array}$ & $\begin{array}{l}3.05 \\
3.38 \\
2.58 \\
2.39 \\
2.26\end{array}$ & $\begin{array}{l}1.84 \\
2.23 \\
1.63 \\
1.53 \\
1.20\end{array}$ & $\begin{array}{l}3.05 \\
3.16 \\
2.07 \\
2.19 \\
2.46\end{array}$ & $\begin{array}{l}4.32 \\
3.14 \\
3.27 \\
2.68 \\
2.41\end{array}$ & $\begin{array}{l}3.03 \\
2.88 \\
2.41 \\
2.42 \\
2.18\end{array}$ \\
\hline $\begin{array}{l}\text { Russian wildrye } \\
\text { Sicklepod milkvetch } \\
\text { Alfalfa } \\
\text { Sainfoin } \\
\text { Grass only } 60 \mathrm{~cm} \text { rows } \\
\text { Grass only } 30 \mathrm{~cm} \text { rows }\end{array}$ & $\begin{array}{l}1.77 \\
1.94 \\
1.46 \\
1.36 \\
1.50\end{array}$ & $\begin{array}{l}2.57 \\
2.22 \\
1.64 \\
2.20 \\
1.80\end{array}$ & $\begin{array}{l}2.64 \\
3.23 \\
2.12 \\
2.77 \\
1.58\end{array}$ & $\begin{array}{l}2.74 \\
3.41 \\
2.23 \\
2.08 \\
1.82\end{array}$ & $\begin{array}{l}1.53 \\
2.28 \\
1.33 \\
1.32 \\
0.81\end{array}$ & $\begin{array}{l}3.29 \\
3.93 \\
3.10 \\
2.87 \\
2.35\end{array}$ & $\begin{array}{l}3.52 \\
3.42 \\
2.58 \\
1.73 \\
1.65\end{array}$ & $\begin{array}{l}2.58 \\
2.92 \\
2.07 \\
2.05 \\
1.64\end{array}$ \\
\hline $\begin{array}{l}\text { Pubescent wheatgrass } \\
\text { Sicklepod milkvetch } \\
\text { Alfalfa } \\
\text { Sainfoin } \\
\text { Grass only } 60 \mathrm{~cm} \text { rows } \\
\text { Grass only } 30 \mathrm{~cm} \text { rows }\end{array}$ & $\begin{array}{l}2.19 \\
1.82 \\
1.61 \\
2.47 \\
1.86\end{array}$ & $\begin{array}{l}2.15 \\
2.28 \\
2.00 \\
2.61 \\
1.99\end{array}$ & $\begin{array}{l}3.28 \\
3.27 \\
2.75 \\
3.24 \\
2.65\end{array}$ & $\begin{array}{l}2.63 \\
3.38 \\
2.54 \\
2.48 \\
2.12\end{array}$ & $\begin{array}{l}1.36 \\
2.00 \\
1.16 \\
1.47 \\
1.19\end{array}$ & $\begin{array}{l}0.37 \\
1.72 \\
0.20 \\
1.08 \\
0.46\end{array}$ & $\begin{array}{l}1.45 \\
2.61 \\
1.35 \\
1.55 \\
0.08\end{array}$ & $\begin{array}{l}1.92 \\
2.44 \\
1.66 \\
2.13 \\
1.58\end{array}$ \\
\hline Isd $0.05^{2}$ & 0.37 & 0.40 & 0.53 & 0.64 & 0.48 & 0.53 & 1.35 & 0.34 \\
\hline
\end{tabular}

IPlots originally planted to grass and crownvetch. The crownvetch died out the first year leaving widely spaced grass rows.

${ }^{2}$ Least significant difference, $\alpha=0.05$.

between that of grass and legume components with the protein content of the various mixtures depending primarily on the amount each component contributed to the mixture. Protein content of grasses grown in mixture with legumes was no higher than that of grasses grown alone. Soil nitrogen was not significantly correlated with either percentage protein in the herbage $(r=0.24)$ or herbage production $(r=0.13)$. The phosphorus $(\mathrm{P})$ content of the herbage showed no consistent relationship to treatment and was not related to the amount of $P$ in the soil $(r=0.01)$. Herbage $P$ levels averaged $1194 \mu \mathrm{g} / \mathrm{g}$ which was below levels generally considered necessary to meet the requirements of (producing) range livestock (NRC 1970).

\section{Conclusions}

Sicklepod milkvetch or alfalfa increased total forage production and crude protein percentage when planted with crested wheatgrass or Russian wildrye. The increase in yield from alfalfa continued at least for 1 year after the alfalfa had disappeared from the plots. The reasons why these 2 legumes increased herbage yield remain unclear. Perhaps, by fixing nitrogen, the legumes provided themselves with a level of nitrogen that stimulated their growth, but, because the associated grasses showed no stimulation, it must be assumed that none of the fixed nitrogen became available to the grasses. When the legumes died, this additional nitrogen should have become available to the grasses. However, sampling of the soils did not indicate any nitrogen increase.

Because of its persistence, sicklepod milkvetch was the best legume species tested for planting with crested wheatgrass or Russian wildrye for range seedings. Alfalfa might have persisted longer if it had been possible to keep the pocket gophers under control. The experimental site was too dry for pubescent wheatgrass; this grass should be restricted to sites receiving considerably more precipitation than $36 \mathrm{~cm} /$ year. Sainfoin was less effective than alfalfa or sicklepod milkvetch for increasing forage yield and was less persistent. This species is not suited for range seedings in this region.

\section{Literature Cited}

Isaac, R.A., and W.C. Johnson. 1976. Determination of total nitrogen in plant tissue, using a block digestor. J. Assoc. Off. Anal. Chem. 59:98-100.

Ludwick, L.E., and A.D. Smith. 1977. Yield and composition of alfalfa and crested wheatgrass, grown singly and in mixture, as affected by $\mathbf{N}$ and $\mathbf{P}$ fertilizers. Can. J. Plant Sci. 57:1077-1083.

National Research Council (NRC). 1970. Nutrient Requirements of Beef Cattle. Fourth revised edition. National Academy of Sciences, Washington, D.C.

Rogler, G.A., and R.L. Lorenz. 1969. Pasture productivity of crested wheatgrass as influenced by nitrogen fertilization and alfalfa. USDA Tech. Bul. 1402. 33 p.

Rumbaugh, M.D., D.A. Johnson, and G.A. Van Epps. 1981. Forage diversity increases yield and quality. Utah Sci, 42:114-117.

Townsend, C.E., and W.J. McGinnies. 1972. Establishment of nine forage legumes in the central Great Plains. Agron. J. 64:699-702.

Townsend, C.E., G.O. Hinze, W.D. Ackerman, and E.E. Remmenga. 1975. Evaluation of forage legumes for rangelands of the central Great Plains. Colorado State Univ. Exp. Sta. General Series 942.

Williams, M.C., L.F. James, and A.T. Bleak. 1976. Toxicity of introduced nitro-containing Astragalus to sheep, cattle, and chicks. J. Range Manage. 29:30-33. 